\title{
The Effect of Note-Taking Strategy Training on Passage Listening Comprehension
}

\author{
Xiaoli Bao ${ }^{1}$ \\ ${ }^{1}$ School of Foreign Language, Inner Mongolia University for Nationalities, No. 536, Huolinhe St, Ke'erqin, \\ Tongliao, Inner Mongolia, China \\ Correspondence: Xiaoli Bao, School of Foreign Language, Inner Mongolia University for Nationalities, No. 536, \\ Huolinhe St, Ke'erqin, Tongliao, Inner Mongolia, China. E-mail: nmbaoxiaoli@163.com
}

Received: September 15, $2020 \quad$ Accepted: October 25, $2020 \quad$ Online Published: November 13, 2020

doi:10.5539/ijel.v10n6p431 URL: https://doi.org/10.5539/ijel.v10n6p431

\begin{abstract}
This study aims at exploring the effects of note-taking strategy on passage listening performance of college students and its implications for listening teaching. For this purpose, the author carried out a study for 15 weeks in Inner Mongolia University for Nationalities. The subjects are divided into experimental class and control class. The teaching method used in the experimental class focuses on incorporating the note-taking strategy training into listening courses and the teaching method used in the control class follows the normal one without the training process of note-taking strategy. The instruments include the pre-test, the post-test, pre-questionnaire and post-questionnaire, and the data collected from the study are analyzed through SPSS17.0.

The major findings show note-taking strategy has a positive effect on college students' passage listening comprehension. After a period of note-taking training, students' comprehensive competence in listening has improved to some extent. 2) Taking notes as much as possible is not an efficient way to get high-quality notes. The number of questions answerable from the notes is proved closely correlated with achievement of listening comprehension. The other three indices of the total number of notes, the content words notes and the notations have no significance with subjects' quality of answer.
\end{abstract}

Keywords: note-taking strategy, passage listening, training

\section{Introduction}

Among the many learning strategies, note-taking strategy is often neglected. Listening note-taking strategy is a basic skill that English learners should master. It is also an indispensable auxiliary means in TEM 8, IELTS, TOEFL and other important examinations. Students' listening note-taking ability is supposed to improve under the direction of the teacher. However, teacher nowadays neglect the cultivation of students' note-taking ability. Although some teachers require students to take notes while listening, they do not tell students what to take and how to take. As a result, students just aimlessly record non-key information, which will not only increase the listening burden and hinder listening comprehension, but also affect the effect of listening training.

This study aims at exploring whether the college students' competence of short passage listening comprehension can be improved through the training of note-taking strategy. It tries to answer two questions:

1) Does note-taking strategy have a positive effect on Chinese college students' short passage listening comprehension after a period of training?

2) What is the relationship between the quantity of the notes and the quality of the answers performed by the students?

\section{Theory}

\subsection{Relevant Study of Note-Taking}

\subsubsection{Definition of Note-Taking}

Rebecca L. Oxford's (1986) views note-taking as one of the most important cognitive strategies, defining it as "writing down the main idea or specific points".

O’Malley and Chamot (1990) define note-taking as "writing down key words and concepts in abbreviated verbal, 
graphic, or numerical form to assist performance of a language task".

Note-taking is a central aspect of a complex human behavior related to information management involving a range of underlying mental processes and their interaction with other cognitive functions (Piolat, Olive, \& Kellogg, 2005).

Alan (2001) points out that "note-taking as a process in which instructional stimuli are converted and recorded in mental units that allow the stimuli to be more easily recalled than if the learner did not participate in note-taking".

Chen (2009) believes that note-taking strategy is a learning strategy to help the brain remember in the process of listening comprehension.

Although scholars expressed in different ways, but it's not hard to see that these views have in common, that is, note-taking strategy is schemata learners build in the brain in the process of listening, is the learning strategy shown in written form. It can help the learners understand, memorize and review the content of the listening material, to distinguish useful information from useless information, thus improve the listening ability.

\subsubsection{Functions of Note-Taking}

Di Vesta and Gray (1972) first distinguished between note encoding function and external storage function.

Encoding function refers to that the process of note-taking itself is beneficial for learners to encode the information so as to help them memorize the information. This function was tested by comparing the memory performance of two groups of subjects: one group took notes while listening; the other group listened without taking notes. The core of the hypothesis of encoding function is that note-taking can stimulate positive learning activities, facilitate the organization of memory and lead to positive transformation. Encoding functions can assist learners in cognitive processing, such as encoding, integration, synthesis and transformation so that auditory stimuli are converted into meaningful forms and stored in the brain. What the learner has recorded represents what he is thinking about. When asked to take notes, they tend to record the most familiar or simple content and represent it in the simplest way. Some typical note-taking methods (acronyms, punctuation, lines, charts, etc.) are often used by learners. For example, replace "one year" with "1 y"; Use the arrow " $\rightarrow$ " instead of "result in" or "lead to"; Use ">" instead of "bigger than"; 30,660,000 to highlight the number; Use "it is expensive" to highlight "expensive". This process of converting auditory information into written information is the encoding function of notes, which enables large amounts of information to be stored in the brain in a reasonable form, and different people record information in different ways. To some extent, learners must reprocess, encode and store the information in long-term memory, so as to integrate the new information into their own cognitive structure and make the new information truly meaningful.

External storage function refers to that it is conducive to the extraction of information after reviewing notes so as to help the memory of information. It is tested by comparing the memory performance of two groups of subjects: one group of subjects is not allowed to review after taking notes, and the other group of subjects is allowed to review their own notes. Di Vesta (1972) believes that external storage can help those who take notes to memorize the content of listening materials and provide the possibility to complete related tasks. Hartley (1983) and Kiewra (1985) found that students who were allowed to review notes had better memory performance than those who were not. This result can be explained by the theory of external memory aid: since people's memory capacity is limited, sometimes they need to use mnemonics or external memory aid to help memory. Mnemonics refers to the use of internal strategies or methods to make it easier to encode, store and retrieve information, while external memory aids refer to the use of external strategies such as lists, underlines, and notes, etc. to help memory. Therefore, note-taking strategy is a written form of external memorization aid method. But why do note-taking strategies help memory? Memory aid theory holds the opinion that information recorded in the notes is stored in the form of schema in the human brains. Therefore, the phenomenon that different people will record the different notes just explains the knowledge structure of long-term memory (schema) is different. Although people use underline, arrows, acronym etc. to take note, for different people, these methods or symbols represent different meanings. For note-takers, it is easier to recall the content of the listening material when they have to recall it, because the content recorded in the notes has been integrated into the knowledge structure of their own brain. From this point of view, external storage function plays an important role in long-term memory, and it can help people to retrieve information in long-term memory, which is also helpful for memory.

\subsubsection{Indices Measuring the Content of Notes}

Native and foreign language researchers are unclear as to what actually should be considered as "good notes", and whether certain aspects of notes indicate successful information processing. In Dunkel's research (1988), she 
develops five-index assessment for the content of notes: 1) the total number of words and notations; 2) the number of information units; 3 ) the number of test questions answerable from the notes. 4) the completeness of the notes and 5) the efficiency of the notes. In a technical report of the ESL center at University of Hawaii, Chaudron (1988) further summaries the measurement of the content of notes as shown below:

Table 1. Measurement of the content of notes

\begin{tabular}{ll}
\hline Total words & Abbreviations, symbols, etc. \\
\hline Total information units & The total number of information units contained in students' notes \\
Efficiency or density & Ratio of information units or ideas to total words verbatim versus telegraphic or abbreviated forms \\
completeness & Ratio of total information units or ideas in notes to main information units or ideas in text \\
Test answerability & Number of information units or ideas pertinent to test items. \\
Number and proportion of high order & Relative to low order text \\
information & \\
Other organizational features & The use of outlining, diagrams, symbols, numbering, evidence of examples, titles. \\
\hline
\end{tabular}

Source: Chaudron, 1988.

Table 1 provides us a full scale of measurement and reflects the features in both quantity and quality of the content of notes. In Chaudron and his fellows' study, the results present that numbers, diagram, notations and content words are proved significant correlation with recalling performance.

The author in this research decides to use Chaudron's (1988) and Liu (2001) views and some previous studies for reference.

\subsubsection{Previous Studies on Note-Taking}

Dunkel (1985) studied the performance of note-taking behavior of second language learners in listening comprehension test. The subjects were allowed to take notes, but were not allowed to see the contents of notes before and during the test. This study did not find a positive effect of learners' note-taking behavior, but subjects' English proficiency had a positive effect on listening comprehension and test results. In addition, Dunkel found that learners who were good at short-term memory did better on listening tests.

Carrel, Dunkel and Mollaun (2002) conducted a study to examine the effects on ESL listening comprehension of note-taking (allowed or disallowed) in relation to lecture length and topic. Two hundred and thirty-four ESL students took tests of listening comprehension. The results revealed in 1) interaction between note-taking and topic: on arts topics listeners performed least well when no note-taking was allowed, better when note-taking was allowed, and about the same on physical science topics whether note-taking was allowed or disallowed. 2) interaction between note-taking and lecture length: on short lectures listeners performed better when note-taking was allowed, less well when note-taking was not allowed, and about the same on longer lectures whether note-taking was allowed or not.

Carrier's (2003) study tested the hypothesis that targeted listening strategy instruction in the ESL classroom results in improved listening comprehension that can be useful in English language learners' academic content classes. After receiving 15 listening strategy training sessions, participants showed a statistically significant improvement in discrete and video listening ability, as well as note-taking ability. This study suggests that targeted listening strategy instruction should be part of the ESL curriculum.

Chaudron, Cook and Loschky (1988) studied the influence of external storage function of notes on second language learners. Different from Dunkel's (1985) experiment, subjects were allowed to take notes and could view or not view notes in the test. The results showed that whether or not they looked at their notes did not affect their performance.

It is worth mentioning that most of the studies abroad focus on native English learners, and few on non-native English learners. Even so, the research conclusions of foreign scholars are quite different: some studies show that note-taking strategies have a negative effect on listening comprehension; some studies show that note-taking strategies have a positive effect on listening comprehension, and some studies show that note-taking strategies have no effect on listening comprehension. It can be seen that foreign scholars have not reached a unified conclusion on the impact of note-taking strategies.

Most of the research subjects in foreign countries are the note-taking strategies of native English speakers. On the contrary, most studies in China focus on the note-taking strategies of EFL learners. 
Liu (2006) conducted a research on note-taking function: the subjects were divided into three groups: the first group was not allowed to take notes, the second group was allowed to take notes but not allowed to review, and the third group was allowed to take notes and review. The test results show that reviewing notes has obvious help to recall specific information, but has no obvious help to recall overall information. In addition, Liu found three points by analyzing the content of the subjects' notes in this experiment: 1) In the detailed questions, the more the number of notes, the higher the score. Therefore, when faced with such questions, students should be encouraged to record the information they hear as much as possible. 2) In the detailed questions, the more complete the spelling of notes (words), the lower the score. Therefore, Liu believes that teachers should teach students shorthand methods and encourage students to develop their own unique shorthand methods. In the listening test, if the time and other factors limit the word to be spelled out, use shorthand in order to avoid affecting the subsequent listening process. 3 ) The number of symbols is positively correlated with the listening performance.

Li (2007) studied the methods of listening note-taking, looking for ways to improve the listening ability of non-English majors from the perspective of the generation mechanism of memory and note-taking strategies.

Zhou (2007), taking non-English majors as the object, explored the factors affecting the listening comprehension of short passages through tests, comparative analysis and questionnaire survey, and found that the longer the length of listening materials, the greater the positive effect of notes. Compared with detailed questions, note-taking strategies are more effective in solving general or general questions, but the results do not show that students who learn note-taking strategies perform better than those who do not.

Yang (2009) on the basis of cognitive principles, proposed that the positive effect of note-taking strategies largely depends on the efficiency of students' long-term memory. In other words, notes only serve as a reminder, while English listening mainly focuses on the application process of long-term memory.

Tai (2015) studied the note quality of academic lectures. Taking Section A of listening task of TEM-8 in 2015 as the material, Tai required the examinees to take notes while listening, and then completed 10 questions. When doing the questions, they could refer to the notes. The research results show that the quality of notes is positively correlated with the understanding of lecture content to some extent, so teachers should pay attention to the cultivation of students' note-taking strategies, especially the note-taking quality, in listening teaching.

Many scholars have studied on the relationship between note-taking and listening comprehension. Most of the studies are carried out abroad, which are not suitable for Chinese listening teaching model. Chinese listening teaching has its own model, which usually takes listening as a passive process. Therefore, there is wide space for applying note-taking into Chinese listening class.

In addition, when conducting the study, the subjects are tried as a whole, without considering the subjects' individual difference or ability level difference, which makes each scholar's research conclusion similar to that of the abroad-some scholars find note-taking strategies have a positive effect on second language learners' English listening comprehension, some scholars believe note-taking strategies have a negative effect, some scholars think note-taking strategies have no significant effects on the learners' listening comprehension. It can be seen that domestic scholars have not formed a unified conclusion on the impact of note-taking strategies.

\subsection{Memory and Listening Comprehension}

\subsubsection{Introduction to Memory}

Atkinson and Shiffrin (1968) first proposed three memory systems, which are called the multi-store model of memory. According to this model, memory can be divided into three forms: sensory store, short-term store and long-term store. This new model has a great influence, because it attracts a lot of attention, which makes it more and more complete in theory and keeps its vitality, and has been supported by biology (Baddeley, 1990, 1997; Groeger, 1997). Baddeley and Hitch (1974) made the system more systematic. They replaced the short-term memory with working memory. The new system of memory can be shown in the following figure.

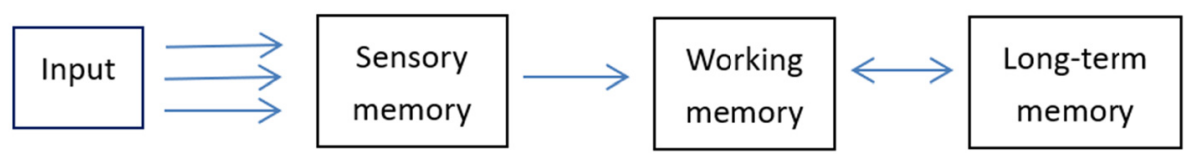

Figure 1 . The model of memory 
According to psychology, memory is the process by which information is encoded, stored and retrieved. Wood (1993) schematizes the processes of remembering as follows:

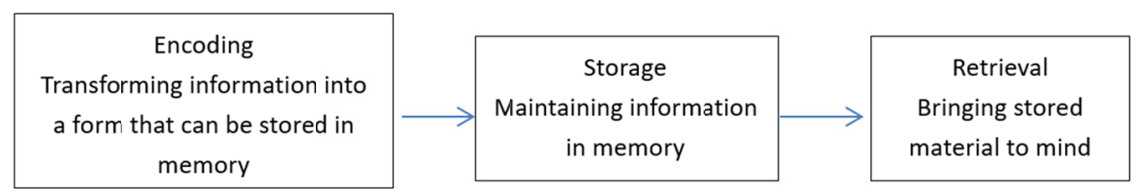

Figure 2. The process required in remembering

Source: Wood, 1993.

If all three processes are implemented, it can be called a successful memory performance; On the contrary, the failure of any one of these three processes may affect the next stage of memory and eventually lead to the failure of memory. Encoding allows information from outside world to reach our sense organs in the forms of chemical or physical stimuli. In this stage information must be transferred into the encoding process. Storage entails the process of maintaining information over periods of time. Retrieval refers to the process of utilizing the information that encoded and stored as knowledge representation in long-term memory.

\subsubsection{Process of Memory}

We know that memory can be divided into sensory memory, short-term memory and long-term memory.

The first process is sensory memory. Klatzky (1984) believes that environmental stimuli acting on the human body's receptors are the beginning of information acquisition. Sensory storage responds to external stimuli and stores information such as color, smell, sound, taste and pressure. It enables individuals to acquire sensory information and preserve it within a short period of time after being stimulated, but usually for no more than four seconds. In addition, as individuals must selectively accept external stimuli according to the learning purpose; attention plays an important role in the process of memory, which determines the perception degree of information in a certain sense, so not all information can reach its "destination". Sternberg (1990) points out that selection and division are the two main functions of attention. Milliken, et al. (1998) believes that "The area of study that concerns itself with the ability to respond selectively to relevant sources of information, while ignoring irrelevant sources of information, is that of selective attention". As the first process of information generation, sensory memory stores information in a textual form that cannot be analyzed. In this stage, a lot of information is quickly forgotten because it doesn't fit the goal, but it is the sensory memory that allows us to select useful information and transfer it to the next stage. The purpose of English listening is to improve the ability to acquire sound information. However, it is impossible to remember all the information in the process of continuous input of sound memory to the brain. Therefore, it is necessary to select the main information purposefully and use the form of notes to help memory.

The second process is working memory. Generally speaking, working memory refers to the memory stored in the brain after sensory memory is selected and processed. Baddeley (1992) argues that working memory is not a unitary system, but can be divided into many components, including two "slave systems" and a "central executive system". Slave system is for the maintenance of visual and phonological information, and central executive "is involved in operating extracting information from longer term memories, selection and implementation of strategies, attention, planning, decision making and even consciousness" (Groeger, 1997). The slave system consists of two sub-components. One is the phonological loop, which holds the function of storing phonologic information and prevents it decay by continuously articulating its contents, thereby refreshing the information in a rehearsal loop. The other slave system is visuo-spatial sketchpad, which is in charge of storing visual and spatial information. It can be used for constructing visual images and for the reflection of mental maps. Figure 3 is the multi-component model of working memory. 


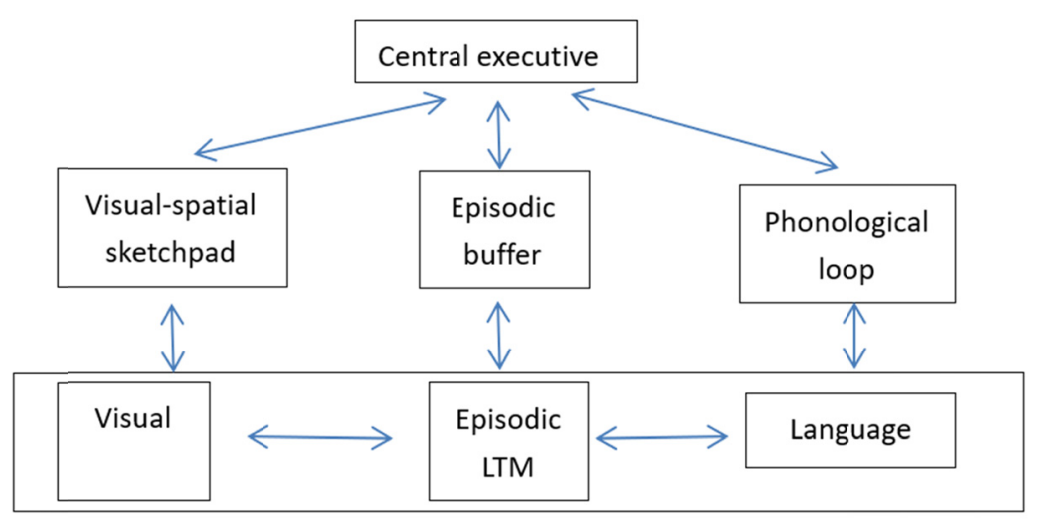

Figure 3. The multi-component model of working memory

Source: Baddele, 2000.

Working memory has a very limited capacity and can hold information for only a short time, but unlike sensory memory, it stores information with the purpose of protecting information from being replaced by new sensory stimuli. George Miller (1968) suggests that the limit of our capacity of processing information is the magical number: $7 \pm 2$. If more information is to be retained, we must enlarge the capacity of each of the seven units by chunking several items into a larger group.

The third process is long-term memory. Atkinson and Schiffrin's multi-store model of memory assumes that all past knowledge is stored in long-term memory, a repository of knowledge and experience. A commonly accepted view of the classification of knowledge in long-term memory is to be divided it into narrative knowledge and procedural knowledge. According to Tulving (1989), narrative knowledge is knowledge that can be used to describe "what", whereas procedural knowledge is knowledge that can be used to describe "how". For example, it is procedural knowledge to remember the meaning of "the Spring Festival" and know that it is a traditional festival in China, while it is procedural knowledge to know that the whole family will get together during the Spring Festival and have dinner and set off firecrackers. Both structurally and functionally, long-term memory is very different from sensory and working memory. Information stored in working memory can only be kept for a short time, but when it is linked to long-term memory, it is strengthened. The longer the information remains in working memory, the stronger its association with long-term memory. Information in long-term memory can be extracted after being prompted by a clue, but this process requires two steps. First, the environment or context serves as a clue, providing the possibility to extract the underlying information. Subsequently, this underlying information is extracted or not extracted.

Because the information in the long-term memory inevitably will be forgotten as well, therefore, the information need to be often awakened in order to be placed in memory for a long time, and this requires the information to be processed from the deeper level, that is to say, the more frequent and the more careful the information is processed, the better and the more systematic it can be stored in long-time memory. On the contrary the information will be forgotten.

\subsubsection{Process of Listening Comprehension}

Carroll (1999) provides an information processing model, which is shown in Figure 4. This information processing model can be applied to a wide range of activities and gives us insight into the listening process. 


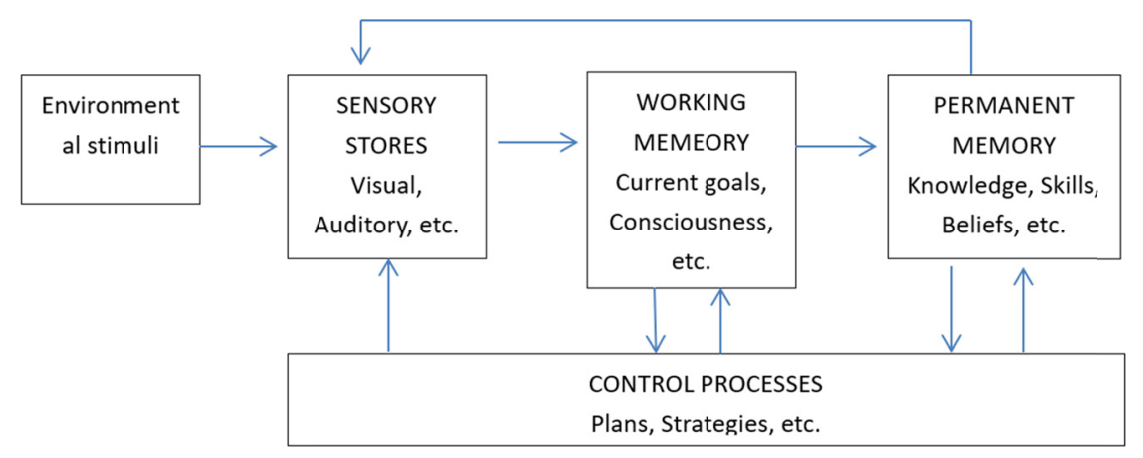

Figure 4. A general modal of information processing

Source: Carroll, 1999.

The process of listening comprehension is divided into three interdependent stages: perception, analysis and application. In the first stage of perception, the listener receives vocal symbols and stores them into sensory memory; information stays for a short time here less than four seconds, and old information will be immediately replaced by new ones. In this stage, human brain will selectively pay attention to the information that is in relevant with current task or is important, such as key words, pauses, stresses and tones, which can be helpful to distinguish and explain the meanings. For the second stage of analysis, relatively simple propositions are screened out, and the original sequence of words therefore forms a representation with meaning as the foundation, and is retained in working memory. And then, the listener connects the received information and the known knowledge in long-term memory in the last stage of application. Background knowledge is stored in long-term memory in the form of propositions other than original words, while new information establishes a connection with background knowledge by stimulating these propositions. Seen from this structure, listening comprehension is bound up with remembering.

Two distinguished views can be used to explain listening comprehension: the bottom-up view and the top-down view. The application of linguistic knowledge in comprehension is usually termed bottom-up processing, whereby the sounds words, clauses and sentences of a passage are decoded in a fairly linear fashion to elicit meaning (Rost, 2002). In top down processing, the listeners' knowledge of the topic, the existing knowledge system stored in long-term memory, will interact with the linguistic knowledge to form an interpretation of the text (Buck, 2001).

\section{Method}

\subsection{Research Questions}

Based on memory theory and note-taking strategy theory, this study aims at exploring whether the college students' competence of short passage listening comprehension can be improved through the training of note-taking strategy. It tries to answer these two questions:

1) Does note-taking strategy have a positive effect on Chinese college students' short passage listening comprehension after a period of training?

2) What is the relationship between the quantity of the notes and the quality of the answers performed by the students?

\subsection{Research Subject}

Ninety-nine medical freshmen from Inner Mongolian University for Nationalities were selected as subjects, and they are divided into two classes. Class one is the Experimental Class and Class Two is the Control Class. There are three reasons for choosing these two classes as subjects in this experiment:

1) All the students in EC and CC are sophomores whose age range from 19 to 20. They have learned English from junior middle school. They have learned English for almost seven years.

2) They are enrolled in this university by passing the College Entrance Examinations. They are at the similar English level to some degree.

3) They are required to take English courses, two integrated English classes and one English listening class every week, with 90 minutes each time. They are provided with the same teaching materials and taught by same 
teacher.

4) They will take part in CET-4, so they have the same explicit learning goals.

All these can ensure the reliability and validity of the research results.

\subsection{Research Instruments}

The main experimental tools used in this experiment are the listening test paper (including pre-test paper and post-test paper), the questionnaires and as well as SPSS 17.0.

The listening comprehension test papers consist of a pre-test and a post-test to be finished during class times. The items are all selected from Section B (short passages) of Part Three (listening comprehension) in CET-4 papers that have been tested from 2012 to 2016 so that the difficulties of the listening materials are at the same level. In addition, the reliability and validity of the CET-4 tests are relatively high. Both the pre-test paper and the post-test paper consist of three short passages, with totally ten items and a score each item. Although the short passages require no prior knowledge in any subject-matter area, they are nevertheless classified according to whether the topic related to: a) personal biographies or stories, b) humanities and customs, or c) a subject of general interests. One passage of each type is used in pre-test and one of each type is used in post-test. The items are all presented in the form of multiple choices and they are arranged at the left side of the test paper, with the right side left blank for the use of taking notes. At the beginning of the study, the students in EC and CC are required to take the pre-test paper on March 1st, 2017 and neither of the two classes are urged to take notes during listening progress, that is to say, they can take notes or they may not as they wish. Then after twelve weeks, the students in these two classes take the post-test on July 1st, 2017, and this time, the students in EC are urged to take notes using the methods they have learned while the students in CC still don't receive any urged requirement. At the same time, all the students in the two classes are assigned to do some exercises or quizzes during class times to test whether they have certain improvement. The students in EC are requested to use the methods of note-taking learned in the class while the students in CC don't receive this kind of note-taking training and don't have urged requirement in the process of listening.

Two questionnaires are administered in the present empirical study. Both of them are modeled closely on Hale and Courtney's (1994) and Carrell, Dunkel and Mollaun's (2002). Furthermore, the students are requested to write down their names on the questionnaire paper. The first questionnaire is presented immediately after the pre-test of listening comprehension and is finished by both EC students and CC students. It probes the students' perceptions about their note-taking experiences and habits in their daily study life and the present testing situation. This part of questionnaire is in the form of multiple choices. The second questionnaire is handed out to the students immediately after the post-test and is finished only by the EC students, with the purpose of probing their perceptions about the present testing situation and their attitude towards the two-month training of taking notes. The questionnaire is designed according to the three-point-Likert-scale. The students are given three options: 1 = agree; 2 = disagree; 3 = no feelings either way. The statistics are collected and analyzed to be conducted on the results. The two questionnaires are both written in Chinese.

\subsection{Research Procedures}

The experiment was conducted from Mar. 1st, to July 1st, 2017 and lasted for twelve weeks with two listening sessions every week. Each session is 45 minutes. The methods used in CC followed the routine one without the training process in note-taking strategy. The teacher method used in EC focuses on incorporating note-taking strategy training into listening courses. All the subjects are never told that they are involved into the present study during the whole process of the research for the purpose of ensuring that the subjects' performance will not be influenced.

\subsubsection{Pre-Test}

All the subjects in both EC and $\mathrm{CC}$ are required to take a listening comprehension test at the first listening class of this semester. It aims to check the students' original listening proficiency before the experiment. The pre-test involves three short passages excerpted from CET-4 tested over the past several years. In order to guarantee the quality of test, the teacher should tell the students before the test that their achievements of the test belong to their class performance and would be account for certain proportion of their final examination scores. All the test papers are collected to be marked and all the notes taken by the students are analyzed in detail by the English teacher according to the indices measuring the content of notes.

\subsubsection{Pre-Questionnaire}

Pre-questionnaire is in the form of multiple choices and aims to probe the students' perceptions about their 
note-taking experiences and their habits of using note-taking strategy in their daily study life and in the present testing situation. This part of questionnaires is in the form of multiple choices and written in Chinese in order that the students comprehend each item correctly. All the students are required to answer the questionnaires in class and are supervised by their teacher so that students have more cooperative and serious attitude towards the questionnaires. The students are requested to fill out the questions truthfully and to sign their names at the designated spot of the paper. Fifty-one questionnaires are distributed to students in EC and forty-eight to the students in CC. Finally, all the questionnaires are handed in.

\subsubsection{Training Model}

Some prominent researchers have put forward certain kinds of models of strategy training. One prominent model is developed by Pearson and Dole (1987) in relation to the study of first language but still applicable to foreign language learning as well. This model aims to research isolated strategies including explicit modeling and explanation of the benefits of a specific strategy, extensive functional practice with the strategy, and an opportunity to transfer the strategy to new learning context. In this research, the author adopts Pearson and Dole's model to train the EC students' note-taking strategy in short passage listening comprehension with the reason that this approach is appropriate for single strategy training.

The following steps introduce how this training model functions in note-taking strategy.

1) Introduction to note-taking strategy through examples

2) Definition and explanation.

3) Guided practice with note-taking strategy

(1) To take notes systematically

(2) To take notes selectively

(3) To be good at using identifiable notations, such as abbreviation, symbols, Chinese characters or even stick figures

(4) Not to depend heavily on the notes

4) Self-regulation with note-taking strategy

\subsubsection{Post-Test}

At the end of the research, a post-test is given to the students both in EC and CC to testify that how much their competences of short passage listening comprehension have been improved from note-taking training and normal practice respectively. The three short passages in the post-test are also excerpted from CET- 4 with different passages from the pre-test, and all the items as well as the instructions are arranged in the same way as is used in the pre-test. The only difference in the requirement is that the students in EC are requested to take notes and use the techniques of note-taking they have learnt while in CC there is no specific demand. When the listening comprehension is over, all the test papers are collected to be marked and all the notes taken by the students are analyzed in detail by the English teacher according to the indices measuring the content of notes.

\subsection{Data Collection}

The data collected in this experiment come from the pre-test and post-test paper as well as two questionnaires. After the data collection, the effective data from the pre-test and post-test are typed into the computer and analyzed through SPSS 17.0 for analysis. The Independent Samples T-test, the Paired Samples T-test and Stepwise Regression Technique are used as the statistical methods in the data analysis. Two kinds of comparisons are made. The Independent Samples T-test is used to compare the results of the pre-test and the post-test between EC and CC respectively to see whether there are significant differences in the data. The Paired Samples T-test is adopted to test the other comparisons of the results between the pre-test and post-test in EC and that of in CC respectively to examine whether there are some significant differences in the data. The result of content of the notes is analyzed by the Stepwise Regression Technique to decide which independent variable is closely correlated with the students' performance of listening comprehension test.

\section{Research Results}

\subsection{Result of Pre-Test and Post-Test}

\subsubsection{Independent Sample T-Test}

The following results are about the independent sample t-test of pre-test between EC and CC. 
Table 2. Group statistics on total score for pre-test of EC \& CC

\begin{tabular}{llllll}
\hline \multicolumn{1}{l}{ Group Statistics } & & & & & \\
\hline \multirow{2}{*}{ Pre-test } & Class & $\mathrm{N}$ & Mean & Std. Deviation & Std. Error Mean \\
& EC & 50 & 5.67 & 1.583 & .222 \\
& CC & 49 & 5.65 & 1.550 & .224 \\
\hline
\end{tabular}

Table 3. Independent samples t-test comparison on total score of pre-test between EC and CC

\begin{tabular}{|c|c|c|c|c|c|c|c|c|c|c|}
\hline \multicolumn{11}{|c|}{ Independent Samples Test } \\
\hline & & \multicolumn{2}{|c|}{$\begin{array}{l}\text { Levene's Test for } \\
\text { Equality of Variances }\end{array}$} & \multicolumn{7}{|c|}{ T-test for Equality of Means } \\
\hline & & \multirow[b]{2}{*}{$\mathrm{F}$} & \multirow[b]{2}{*}{ Sig. } & \multirow[b]{2}{*}{$\mathrm{t}$} & \multirow[b]{2}{*}{$\mathrm{df}$} & \multirow[b]{2}{*}{$\begin{array}{l}\text { Sig. } \\
\text { (2-tailed) }\end{array}$} & \multirow[b]{2}{*}{$\begin{array}{l}\text { Mean } \\
\text { Difference }\end{array}$} & \multirow[b]{2}{*}{$\begin{array}{l}\text { Std. Error } \\
\text { Difference }\end{array}$} & \multicolumn{2}{|c|}{$\begin{array}{l}95 \% \text { Confidence Interval } \\
\text { of the Difference }\end{array}$} \\
\hline & & & & & & & & & Lower & Upper \\
\hline \multirow[t]{2}{*}{ Pre-test } & $\begin{array}{l}\text { Equal variances } \\
\text { assumed }\end{array}$ & .003 & .953 & .066 & 97 & .947 & .021 & .351 & -.605 & .646 \\
\hline & $\begin{array}{l}\text { Equal variances } \\
\text { not assumed }\end{array}$ & & & .066 & 96.843 & .947 & .021 & .315 & -.604 & .646 \\
\hline
\end{tabular}

As is shown from Table 2, the mean score of EC is 5.67 while that of CC is 5.65. The difference of mean score between the two classes is little and of not significance. The standard deviation of EC and CC are similar. This means listening competence of the two classes is almost equal. The significant difference (sig.) is 0.953 (> 0.05$)$ and the Sig. (2-tailed) is 0.947 , both of which are more than 0.05 , and the two variables' $95 \%$ confidence interval of the difference is from -0.605 to 0.646 , with zero between them. All These data mean there is no great difference between EC and CC.

Table 4. Group statistics on note-taking score for pre-test of EC \& CC

\begin{tabular}{|c|c|c|c|c|c|}
\hline \multicolumn{6}{|c|}{ Group Statistics } \\
\hline & Class & $\mathrm{N}$ & Mean & Std. Deviation & Std. Error Mean \\
\hline \multirow[t]{2}{*}{ Post-test } & EC & 50 & 1.2353 & .92926 & .13012 \\
\hline & $\mathrm{CC}$ & 49 & 1.2292 & .97281 & .14041 \\
\hline
\end{tabular}

Table 5. Independent samples t-test comparison on note-taking score of pre-test between EC \& CC

\begin{tabular}{|c|c|c|c|c|c|c|c|c|c|c|}
\hline \multicolumn{11}{|c|}{ Independent Samples Test } \\
\hline & & \multicolumn{2}{|c|}{$\begin{array}{l}\text { Levene's Test for } \\
\text { Equality of Variances }\end{array}$} & \multicolumn{7}{|c|}{ T-test for Equality of Means } \\
\hline & & \multirow[b]{2}{*}{$\mathrm{F}$} & \multirow[b]{2}{*}{ Sig. } & \multirow[b]{2}{*}{$\mathrm{t}$} & \multirow[b]{2}{*}{$\mathrm{df}$} & \multirow[b]{2}{*}{$\begin{array}{l}\text { Sig. } \\
\text { (2-tailed) }\end{array}$} & \multirow[b]{2}{*}{$\begin{array}{l}\text { Mean } \\
\text { Difference }\end{array}$} & \multirow[b]{2}{*}{$\begin{array}{l}\text { Std. Error } \\
\text { Difference }\end{array}$} & \multicolumn{2}{|c|}{$\begin{array}{l}95 \% \text { Confidence Interva } \\
\text { of the Difference }\end{array}$} \\
\hline & & & & & & & & & Lower & Upper \\
\hline \multirow[t]{2}{*}{ Pre-test } & $\begin{array}{l}\text { Equal variances } \\
\text { assumed }\end{array}$ & .261 & .611 & .032 & 97 & .974 & .00613 & .19117 & -.37329 & .38554 \\
\hline & $\begin{array}{l}\text { Equal variances } \\
\text { not assumed }\end{array}$ & & & .032 & 95.903 & .975 & .00613 & .19144 & -.37388 & .38613 \\
\hline
\end{tabular}

Table 4 shows the mean score with question answerable notes of experimental class is only 1.2353 while that of control class is only 1.2292 , both being very low and almost having no difference with each other. Table 5 shows the significant difference (sig.) is 0.611 (>0.05), and the Sig. (2-tailed) is 0.974 , both are more than 0.05 , and the $95 \%$ confidence interval of the difference is from -0.37329 to 0.38613 , with zero between them. All these data mean there is no great difference between experimental class and control class with the use of note-taking strategy. Therefore, it can be concluded that the subjects' application to note-taking strategy in the two classes are both in the same level and not very well.

The following results are about the independent samples of post-test between experimental class and control class. 
Table 6. Group statistics on total score for post-test of EC \& CC

\begin{tabular}{|c|c|c|c|c|c|}
\hline \multicolumn{6}{|c|}{ Group Statistics } \\
\hline & Class & $\mathrm{N}$ & Mean & Std. Deviation & Std. Error Mean \\
\hline \multirow[t]{2}{*}{ Post-test } & $\mathrm{EC}$ & 50 & 8.1373 & 1.20033 & .16808 \\
\hline & $\mathrm{CC}$ & 49 & 6.4792 & 1.51573 & .21878 \\
\hline
\end{tabular}

Table 7. Independent samples t-test comparison on total score of post-test between EC \& CC

\begin{tabular}{|c|c|c|c|c|c|c|c|c|c|c|}
\hline \multicolumn{11}{|c|}{ Independent Samples Test } \\
\hline & & \multicolumn{2}{|c|}{$\begin{array}{l}\text { Levene's Test for } \\
\text { Equality of Variances }\end{array}$} & \multicolumn{7}{|c|}{ T-test for Equality of Means } \\
\hline & & \multirow[b]{2}{*}{$\mathrm{F}$} & \multirow[b]{2}{*}{ Sig. } & \multirow[b]{2}{*}{$\mathrm{t}$} & \multirow[b]{2}{*}{ df } & \multirow[b]{2}{*}{$\begin{array}{l}\text { Sig. } \\
\text { (2-tailed) }\end{array}$} & \multirow[b]{2}{*}{$\begin{array}{l}\text { Mean } \\
\text { Difference }\end{array}$} & \multirow[b]{2}{*}{$\begin{array}{l}\text { Std. Error } \\
\text { Difference }\end{array}$} & \multicolumn{2}{|c|}{$\begin{array}{l}95 \% \text { Confidence Interva } \\
\text { of the Difference }\end{array}$} \\
\hline & & & & & & & & & Lower & Upper \\
\hline \multirow[t]{2}{*}{ Pre-test } & $\begin{array}{l}\text { Equal variances } \\
\text { assumed }\end{array}$ & 3.865 & .052 & 6.052 & 97 & .000 & 1.65809 & .27396 & 1.11436 & 2.20182 \\
\hline & $\begin{array}{l}\text { Equal variances } \\
\text { not assumed }\end{array}$ & & & 6.010 & 89.535 & .000 & 1.65809 & .27589 & 1.10995 & 2.20623 \\
\hline
\end{tabular}

It can be seen from Table 6 that the mean score of experimental class is 8.1373 which is almost 2 points higher than that of control class (6.4792). Besides, the standard deviation of experimental class is 1.20033 and control class is 1.51573 , which means that the gaps among the students in experimental class are much smaller than those in control class. It can be seen from Table 7 that the significant difference (sig.) of Levene's Test for Equality of Variances is $0.052(>0.05)$ but the Sig. (2-tailed) shows $0.000(<0.05)$, besides the two variables' $95 \%$ confidence interval of the difference is between -2.84941 and -2.09177 , with no zero between them. These three groups of data mean that there is a significant difference between experimental class and control class in the abilities of listening comprehension. In other words, the statistical data in the two tables indicate the students in experimental class improve much more than the students in control class.

\subsubsection{Paired Sample T-Test}

Table 8. Group statistics on total score for pre-test \& post-test of EC paired samples t-test

\begin{tabular}{llllll}
\hline \multicolumn{2}{c}{ Paired Sample Statistics } & \multicolumn{5}{l}{} \\
\hline \multirow{4}{*}{ Pair 1 } & & Mean & $\mathrm{N}$ & Std. Deviation & Std. Error Mean \\
\cline { 3 - 6 } & Pre-test & 5.6667 & 50 & 1.58325 & .22170 \\
& Post-test & 8.1373 & 50 & 1.20033 & .16808 \\
\hline
\end{tabular}

As is shown in Table 8, the mean score in experimental class for post-test (8.1373) is almost 2.5 points higher than the mean score for pre-test (5.6667). In the meantime, the standard deviation is decreased by 0.38 (pretest: 1.58325; posttest: 1.2033), which means that more students' scores are close to the man score, indicating their gaps are getting smaller. The paired samples t-test is conducted in order to check whether there is significant difference between pre-test and post-test.

Table 9. Paired samples correlations on total score for pre-test $\&$ post-test of EC

\begin{tabular}{lllll}
\hline \multicolumn{2}{l}{ Paired Sample Correlations } & & & \\
\hline & & $\mathrm{N}$ & Correlations & $\mathrm{Sig}$ \\
\cline { 3 - 5 } Pair 1 & Pre-test \& post-test & 50 & .561 & .000 \\
\hline
\end{tabular}

As is seen from Table 9, the correlation between score of pre-test and post-test is 0.561 and the significant difference (sig.) is $0.000(<0.05)$, it is proper to go to the paired sample t-test. 
Table 10. Paired samples t-test on total score for pre-test \& post-test of EC

\begin{tabular}{|c|c|c|c|c|c|c|c|c|c|}
\hline \multicolumn{10}{|c|}{ Paired Sample Test } \\
\hline & & \multicolumn{5}{|c|}{ Paired differences } & \multirow[t]{3}{*}{$\mathrm{t}$} & \multirow[t]{3}{*}{$\mathrm{df}$} & \multirow{3}{*}{$\begin{array}{l}\text { Sig. } \\
\text { (2-tailed) }\end{array}$} \\
\hline & & \multirow[t]{2}{*}{ Mean } & \multirow[t]{2}{*}{$\begin{array}{l}\text { Std. } \\
\text { Deviation }\end{array}$} & \multirow[t]{2}{*}{$\begin{array}{l}\text { Std. Error } \\
\text { Mean }\end{array}$} & \multicolumn{2}{|c|}{$\begin{array}{l}95 \% \text { Confidence Interval of } \\
\text { the Difference }\end{array}$} & & & \\
\hline & & & & & Lower & Upper & & & \\
\hline Pair 1 & $\begin{array}{l}\text { Pre-test \& } \\
\text { post-test }\end{array}$ & -2.47059 & 1.34689 & .18860 & -2.84941 & -2.09177 & -13.099 & 50 & .000 \\
\hline
\end{tabular}

As is shown from Table 10, the two variables' (pre-test scores and post-test scores for experimental class) 95\% confidence interval of the difference is between -2.84941 and -2.0917 , with no zero between them, which indicates there is a significant difference between them. Besides, the Sig (2-tailed) is 0.000, far less than 0.05 .

Tables 8,9 and 10 show that the difference of experimental class's subjects performances in pre-test and post-test are significant. They performed much better in post-test than in pre-test.

Table 11. Paired samples statistics of total score and note-taking score of EC in post-test

\begin{tabular}{llllll}
\hline \multicolumn{2}{l}{ Paired Sample Statistics } & & & & \\
\hline & Mean & $\mathrm{N}$ & Mean & Std. Deviation & Std. Error Mean \\
\hline Pair 1 & Total & 8.1373 & 50 & 1.20030 & .16808 \\
& Notes & 6.4706 & 50 & 1.30158 & .18226 \\
\hline
\end{tabular}

As is seen from Table 11, the mean score of the students in post-test is 8.1373 while the mean score according to answerable notes is 6.4706 . This group of data shows that the correct item numbers according to the notes accounts for a large proportion in the total number of correct items, in other words, the note-taking strategy plays an important role in the process of listening comprehension.

Table 12. Group statistics for pre-test \& post-test of CC

\begin{tabular}{llllll}
\hline \multicolumn{2}{l}{ Paired Sample Statistics } & & & & \\
\hline Pair 1 & & Mean & $\mathrm{N}$ & Std. Deviation & Std. Error Mean \\
& Pre-test & 5.6458 & 49 & 1.55042 & .22378 \\
& Post-test & 6.4792 & 49 & 1.51573 & .21878 \\
\hline
\end{tabular}

Table 13. Paired samples correlations for pre-test \& post-test of CC

\begin{tabular}{lllll}
\hline \multirow{2}{*}{ Paired Sample Correlations } & \multicolumn{3}{l}{} \\
\cline { 3 - 5 } & $\mathrm{N}$ & Correlations & Sig \\
\hline Pair 1 & Pre-test \& post-test & 49 & .554 & .000 \\
\hline
\end{tabular}

Table 12 shows the subjects' mean score in control class for post-test is 6.4792 while the mean score for pre-test is 5.6458 , only 0.8 points increase, which means that the students' performance in post-test is a little better than in pre-test. Table 13 shows the significant difference is $0.000(<0.05)$, which indicates the significant difference exists between the two test results.

Table 14. Paired samples t-test for pre-test $\&$ post-test of CC

\begin{tabular}{|c|c|c|c|c|c|c|c|c|c|}
\hline \multicolumn{10}{|c|}{ Paired Sample Test } \\
\hline & & \multicolumn{5}{|c|}{ Paired differences } & \multirow[t]{3}{*}{$\mathrm{t}$} & \multirow[t]{3}{*}{$\mathrm{df}$} & \multirow{3}{*}{$\begin{array}{l}\text { Sig. } \\
\text { (2-tailed) }\end{array}$} \\
\hline & & \multirow[t]{2}{*}{ Mean } & \multirow[t]{2}{*}{$\begin{array}{l}\text { Std. } \\
\text { Deviation }\end{array}$} & \multirow[t]{2}{*}{$\begin{array}{l}\text { Std. Error } \\
\text { Mean }\end{array}$} & \multicolumn{2}{|c|}{$\begin{array}{l}95 \% \text { Confidence Interval of } \\
\text { the Difference }\end{array}$} & & & \\
\hline & & & & & Lower & Upper & & & \\
\hline Pair 1 & $\begin{array}{l}\text { Pre-test } \\
\& \text { post-test }\end{array}$ & -8.3333 & 1.44889 & .20913 & -1.25405 & -.41262 & -3.985 & 47 & .000 \\
\hline
\end{tabular}

As is seen from Table 14, the two variables' (pre-test scores and post-test scores for CC) $95 \%$ confidence interval 
of the difference is between -1.25405 and -0.41262 , with no zero between them, which indicates that there is a significant between them. In addition, the Sig. (2-tailed) is 0.000 , far less than 0.05 .

Tables 12, 13 and 14 show that the difference between the control class subjects' performances in pre-test and post-test is significant. They perform a little better in post-test than in pre-test but the improvement is not as obvious as the students in experimental class.

\subsection{Results of Questionnaires}

\subsubsection{Data from Pre-Questionnaire}

The following table is concerned with the frequency and percentage of the students' different background of note-taking instruction and habits.

Table 15. Questions about note-taking instruction and habits: Proportions of students giving each response

\begin{tabular}{|c|c|c|c|c|c|}
\hline & & \multicolumn{2}{|c|}{$\mathrm{EC}(\mathrm{N}=50)$} & \multicolumn{2}{|c|}{$\mathrm{CC}(\mathrm{N}=49)$} \\
\hline & & $\mathrm{F}$ & $\mathrm{P} \%$ & $\mathrm{~F}$ & $\mathrm{P} \%$ \\
\hline \multirow[t]{2}{*}{ Statement 1} & Yes & 6. & 12.0 & 6 & 12.2 \\
\hline & No & 44 & 88.0 & 43 & 87.7 \\
\hline \multirow[t]{4}{*}{ Statement 2} & $<1 \mathrm{hr}$ & 3 & 6.0 & 3 & 6.1 \\
\hline & 1-3 hrs. & 3 & 6.0 & 1 & 2.0 \\
\hline & $3-5$ hrs. & 0 & 0.0 & 1 & 2.0 \\
\hline & $>5 \mathrm{hrs}$ & 1 & 2.0 & 0 & 0.0 \\
\hline \multirow[t]{2}{*}{ Statement 3} & Yes & 35 & 70.0 & 34 & 69.4 \\
\hline & No & 15 & 30.0 & 15 & 30.6 \\
\hline \multirow[t]{4}{*}{ Statement 4} & $<1 \mathrm{hr}$ & 5 & 10.0 & 6 & 12.2 \\
\hline & 1-3 hrs. & 8 & 16.0 & 13 & 26.5 \\
\hline & $3-5$ hrs. & 12 & 24.0 & 8 & 16.3 \\
\hline & $>5 \mathrm{hrs}$ & 9 & 18.0 & 8 & 16.3 \\
\hline \multirow[t]{4}{*}{ Statement 5} & None & 6 & 12.0 & 6 & 12.2 \\
\hline & Few & 10 & 20.0 & 9 & 18.4 \\
\hline & Some & 20 & 40.0 & 22 & 44.9 \\
\hline & A lot & 14 & 28.0 & 12 & 24.5 \\
\hline \multirow[t]{4}{*}{ Statement 6} & None & 2 & 4.0 & 1 & 2.0 \\
\hline & Few & 7 & 14.0 & 7 & 14.3 \\
\hline & Some & 17 & 34.0 & 17 & 34.7 \\
\hline & A lot & 24 & 48.0 & 24 & 49.0 \\
\hline \multirow[t]{3}{*}{ Statement 7} & English & 16 & 32.0 & 13 & 26.5 \\
\hline & Chinese & 6 & 12.0 & 5 & 10.2 \\
\hline & Both & 26 & 52.0 & 27 & 55.1 \\
\hline \multirow[t]{4}{*}{ Statement 8} & None & 14 & 28.0 & 12 & 24.5 \\
\hline & Few & 23 & 46.0 & 21 & 42.8 \\
\hline & Some & 9 & 18.0 & 13 & 26.5 \\
\hline & A lot & 4 & 8.0 & 3 & 6.12 \\
\hline \multirow[t]{4}{*}{ Statement 9} & None & 16 & 32.0 & 15 & 30.6 \\
\hline & Few & 25 & 50.0 & 22 & 44.9 \\
\hline & Some & 8 & 14.0 & 12 & 24.5 \\
\hline & A lot & 1 & 2.0 & 0 & 0.0 \\
\hline \multirow[t]{3}{*}{ Statement 10} & English & 21 & 42.0 & 22 & 44.9 \\
\hline & Chinese & 4 & 8.0 & 6 & 12.2 \\
\hline & Both & 14 & 28.0 & 8 & 16.3 \\
\hline
\end{tabular}

Note. $\mathrm{N}=$ number, $\mathrm{F}=$ frequency, $\mathrm{P}=$ percentage.

The first four questions indicate the note-taking strategy situation in English class and in Chinese class. In English class, six students received note-taking training in experimental class. Among them, three students received less than one-hour training, four students one to three hours training and only one student more than five hours. The situation is similar in control class. Altogether five students received training. Among them, three students received training for less than one hour, one student one to three hours and one student three to five hours. In Chinese class, the situation is much better for both experimental class and control class, for more than two thirds of students have received note-taking training. Training hours are more than three hours. 
Questions five and six suggest that quantities of notes students take in English class and Chinese class are almost same. About half of students ( $40 \%$ in experimental class and $44.9 \%$ in control class) take down some notes in English class, about another half (48\% in experimental class and $42.9 \%$ in control class) choose "few" or "a lot", while the rest about 12\% students don't take notes in English class at all. The use of note-taking in Chinese class is much wider, nearly half choosing "a lot" (48\% in experimental class and $49 \%$ in control class.

Question eight and nine indicate the quantities of notes the students take on their daily English listening comprehension tests and on the test today. As is seen from the table, most of them choose "few" ( $48 \%$ in experimental class and $43 \%$ in control class), following with the percentages who choose "none" and "some, and very few students choose "a lot" ( $8 \%$ in experimental class and $6.1 \%$ in control class).

Question seven and ten are the use of language when taking notes. More than half of the students $(52 \%$ in experimental class and 55.1\% in control class) can use both English and Chinese to write down notes and some use only English in English class. Most students can use English to take notes, a few less students can use both English and Chinese and very few use only Chinese in today's test.

\subsubsection{Data from Post-Questionnaire}

The post-questionnaire aims at probing experimental students' the perception about the present situation and their attitude towards the training of taking notes.

Table 16. Frequency and percentage distribution with questionnaire statistics on present note-taking training

\begin{tabular}{llllllll}
\hline Statement number & $\mathrm{N}$ & \multicolumn{2}{c}{ Agree } & \multicolumn{2}{c}{ Disagree } & \multicolumn{2}{c}{ No strong feeling } \\
\cline { 2 - 7 } & & $\mathrm{F}$ & $\mathrm{P} \%$ & $\mathrm{~F}$ & $\mathrm{P} \%$ & $\mathrm{~F}$ & $\mathrm{P} \%$ \\
\hline Statement 1 & 50 & 31 & 62 & 10 & 22 & 9 & 18 \\
Statement 2 & 50 & 12 & 24 & 23 & 46 & 15 & 30 \\
Statement 3 & 50 & 37 & 74 & 5 & 10 & 8 & 16 \\
Statement 4 & 50 & 6 & 12 & 35 & 70 & 9 & 18 \\
Statement 5 & 50 & 36 & 72 & 7 & 14 & 7 & 14 \\
Statement 6 & 50 & 5 & 10 & 32 & 64 & 13 & 26 \\
Statement 7 & 50 & 20 & 40 & 10 & 20 & 20 & 40 \\
Statement 8 & 50 & 30 & 60 & 9 & 18 & 11 & 22 \\
Statement 9 & 50 & 3 & 6 & 32 & 64 & 15 & 30 \\
Statement 10 & 50 & 35 & 70 & 6 & 12 & 9 & 18 \\
Statement 11 & 50 & 23 & 46 & 19 & 38 & 8 & 16 \\
Statement 12 & 50 & 8 & 16 & 28 & 56 & 14 & 28 \\
Statement 13 & 50 & 3 & 6 & 37 & 74 & 10 & 20 \\
Statement 14 & 50 & 32 & 64 & 8 & 16 & 10 & 20 \\
Statement 15 & 50 & 24 & 48 & 18 & 36 & 8 & 16 \\
\hline
\end{tabular}

Note. $\mathrm{N}=$ number, $\mathrm{F}=$ frequency, $\mathrm{P}=$ percentage.

The eight statements are about the general aspects of note-taking effect on students and the statements from nine to fifteen are about the specific aspects.

More than half of the students reaped benefits from the training of note-taking strategy, as is seen from the Table $16.62 \%$ think that taking notes helps them answer the questions better; $74 \%$ students felt more at ease when they could take notes than when they could not; $72 \%$ students felt taking notes helps them listen carefully to the passage. $60 \%$ students felt that taking notes helps them remember the information more easily. $40 \%$ students agree taking notes helps them understand the passage, $20 \%$ students didn't agree with that and another $40 \%$ students didn't have any strong feelings either way, which indicates the significance of note-taking strategy in understanding the whole passage is not obvious. $46 \%$ didn't agree taking-notes make them more difficult to understand the passage and $24 \%$ students agreed with that. $70 \%$ students didn't believe taking notes made the answering more difficult and $64 \%$ disagreed taking notes distracted their attention.

Most students didn't agree the statements that taking notes has little help in listening process or finding the correct answers. $64 \%$ students didn't think they want more time to review their notes before answering the questions, while only $6 \%$ students think so, which indicates most of them can use their notes immediately when they want to use without any time wasting. More than half (56\%) students didn't agree they find it difficult to listen to the test questions and at the same time to look for specific information in their notes; only $16 \%$ students agree with that. $74 \%$ students opposed the idea that passage were too short and too easy for taking notes to help 
them very much; only $6 \%$ students thought so. $36 \%$ disagreed that the speed was too fast to takes notes, $48 \%$ students agreed with that and another $16 \%$ didn't have strong feeling either way. From the finding of statements $10,11,14$, we know most students agree that they could use the strategy much better. $70 \%$ students felt they could use the notes when answering the questions; $64 \%$ felt they could find the answers from the notes they had taken. $40 \%$ students agreed that they have enough time to take notes.

\subsection{Results of the Contents of Notes}

A stepwise regression analysis is used to identify which of the four indices, including the number of content words, the number of notations, the number of questions answerable from the notes and the total number of all the notes collected from every experimental class student's post-test notes has the most important effect on the students' performance of listening comprehension test. The following table shows the descriptive statistics on all the variables in the analysis.

Table 17. Descriptive statistics for stepwise multiple regression equation

\begin{tabular}{llllll}
\hline Descriptive Statistics & \multicolumn{5}{l}{} \\
\hline & $\mathrm{N}$ & Minimum & Maximum & Mean & Std. Deviation \\
\hline Total score & 50 & 5.00 & 10.00 & 8.1373 & 1.20033 \\
Content words & 50 & 5.00 & 19.00 & 13.5098 & 3.01578 \\
Notations & 50 & 7.00 & 19.00 & 14.2941 & 3.11316 \\
Questions answerable & 50 & 4.00 & 9.00 & 6.4510 & 1.30098 \\
All notes & 50 & 12.00 & 36.00 & 27.8039 & 5.20008 \\
Valid N & 50 & & & & \\
\hline
\end{tabular}

The extensiveness of the notes ranged from 12.00 to a maximum of 36.00 in the experimental students' post-test and the mean number of notes is approximately 27.80 for every student who took notes. The mean number of content words is nearly 13.51, which is similar to the mean number of notations (14.29). The range for content words is from 5.00 to 19.00 and that for the index of notations is from 7.00 to 19.00 . The number of questions answerable from the notes ranges from 4.00 to 9.00 , with the mean score of 6.45 . The mean of total score is 8.13 with the maximum score of 10.00 and the minimum of 5.00 .

The following table presents the Pearson correlations of the four indices with the subjects' listening comprehension achievement.

Table 18. Pearson correlation of the four indices

\begin{tabular}{|c|c|c|c|c|c|c|}
\hline \multirow[t]{2}{*}{ Correlations } & & \multirow[b]{2}{*}{ Total score } & \multirow[b]{2}{*}{ Content words } & \multirow[b]{2}{*}{ Notations } & \multirow[b]{2}{*}{ Questions answerable } & \multirow[b]{2}{*}{ All notes } \\
\hline & & & & & & \\
\hline \multirow[t]{3}{*}{ Total Scores } & Pearson Correlation & 1 & .022 & .043 & $.702 * *$ & .039 \\
\hline & Sig. (2-tailed) & & .880 & .767 & .000 & .786 \\
\hline & $\mathrm{N}$ & 50 & 50 & 50 & 50 & 50 \\
\hline \multirow[t]{3}{*}{ Content words } & Pearson Correlation & .022 & 1 & $.308^{*}$ & -.116 & $.834 * *$ \\
\hline & Sig. (2-tailed) & .880 & & .028 & .418 & .000 \\
\hline & $\mathrm{N}$ & 50 & 50 & 50 & 50 & 50 \\
\hline \multirow[t]{3}{*}{ Notation } & Pearson Correlation & .043 & $.308^{*}$ & 1 & -.197 & $.782 * *$ \\
\hline & Sig. (2-tailed) & .767 & .028 & & .165 & .000 \\
\hline & $\mathrm{N}$ & 50 & 50 & 50 & 50 & 50 \\
\hline Question & Pearson Correlation & $.702 * *$ & -.116 & -.197 & 1 & -.191 \\
\hline \multirow[t]{2}{*}{ answerable } & Sig. (2-tailed) & .000 & .418 & .165 & & .180 \\
\hline & $\mathrm{N}$ & 50 & 50 & 50 & 50 & 50 \\
\hline \multirow[t]{3}{*}{ All notes } & Pearson Correlation & .039 & $.834 * *$ & $.782 * *$ & -.191 & 1 \\
\hline & Sig. (2-tailed) & .786 & .000 & .000 & .180 & \\
\hline & $\mathrm{N}$ & 50 & 50 & 50 & 50 & 50 \\
\hline
\end{tabular}

Note. **. Correlation is significant at the 0.01 level (2-tailed); *. Correlation is significant at the 0.05 level (2-tailed).

The Pearson Correlation of questions answerable from the notes is 0.702 and Significant Difference is 0.000 ( $<$ 0.01 ), which indicate that the index of questions answerable from the notes correlates significantly with the students' listening comprehension performance. But the index of the total content words $(r=0.022, p=0.880>$ 
$0.05)$, notations $(r=0.043, p=0.767>0.05)$, and total number of notes $(r=0.039, p=0.786>0.05)$ don't correlate significantly with the students' listening comprehension performance. Therefore, only the index-the number of questions answerable from the notes-enters the simple regression equation except the other three.

Table 19. Summary for stepwise regression

\begin{tabular}{lllll}
\hline Model Summary & & & & \\
\hline Model & $\mathrm{R}$ & R Square & Adjusted Square & Std. Error of the Estimate \\
\hline Question Answerable & $.702^{\mathrm{a}}$ & .493 & .483 & .86305 \\
\hline
\end{tabular}

Note. a. Predictors: (Constant), question answerable.

It can be seen from the Table 19 that correlation between the two variables is 0.702 , which means that the number of questions answerable from the notes is closely correlated to the subjects' performance in post-test. The determination coefficient is 0.493 , which shows that there is a significant correlation between the total score and the number of questions answerable from the notes and it also means that nearly half of the test performance results could be predicted by the variable of the number of questions answerable from the notes.

Table 20. Regression coefficients

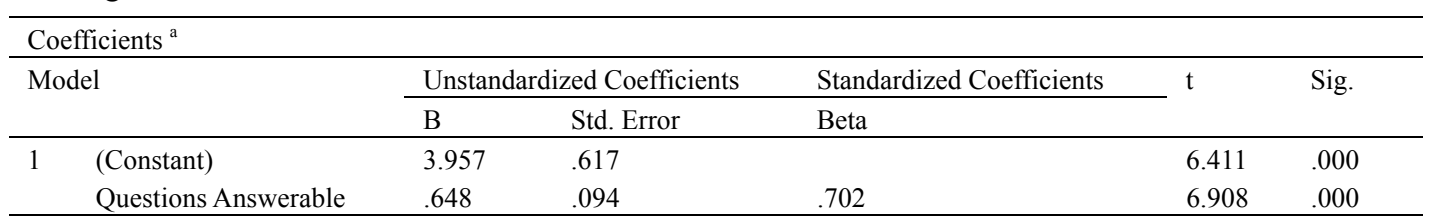

Note. a. Dependent Variable: total score.

As is shown from Table 20, the $\mathrm{T}$ value is 6.908 , far more than 2 , which means that the number of questions answerable from the notes is a useful predictor for the total score.

Table 21. Statistical information of the excluded variables

\begin{tabular}{|c|c|c|c|c|c|}
\hline \multicolumn{6}{|l|}{ Excluded Variables $^{\mathrm{c}}$} \\
\hline \multirow[t]{2}{*}{ Model } & \multirow[t]{2}{*}{ Beta In } & \multirow[t]{2}{*}{$\mathrm{t}$} & \multirow[t]{2}{*}{ Sig. } & \multirow[t]{2}{*}{ Partial Correlation } & Collinearity Statistics \\
\hline & & & & & Tolerance \\
\hline Content words & $.022^{\mathrm{b}}$ & .152 & .880 & .022 & 1.000 \\
\hline Notations & $.043^{\mathrm{b}}$ & .298 & .767 & .043 & 1.000 \\
\hline All notes & $.039^{\mathrm{b}}$ & .273 & .786 & .039 & 1.000 \\
\hline
\end{tabular}

Note. a. Predictors in the Model: (Constant), all notes, notations; b. Predictor: (constant); c. Dependent Variable: total score.

Table 21 presents the three variables remove out of the stepwise regression analysis. Beta In shows the excluded variables' standardized regression coefficients after being taken into account. The three beta ins are all very small $(0.022,0.043,0.039)$. The three $\mathrm{T}$ values are respectively $0.152,0.298,0.273$, which are in the range of -2 and 2 . The partial correlations are much small, too. All the data indicate that there is no co linearity relationship between the three indices and the total score in post-test. In other words, the three variables are not the predictive variables to the test performance.

Therefore, the conclusion can be drawn there is no significant relationship between quantity of the notes and the quality of the answer, and only the number of questions answerable from the notes is a predictor for students' good performance in the listening comprehension test.

\subsection{Discussion}

The conclusion can be drawn from the data that note-taking strategy has a positive effect in college students' short passage listening comprehension after a session of training.

The results of two independent samples t-test of pre-test proves that the listening proficiencies between the two classes are almost at the same level before the experiment, and students' application to note-taking strategy in the two classes are both in the same level. The results of Independent Samples T-test for post-test shows compared 
with the pre-test, both of the two classes' students' listening abilities have been improved, but the students in experimental class have improved much more than those in control class. The data in Paired Samples T-test of control class for pre-test and post-test shows they performed a little better in post-test than in pre-test but the improvement is not as obvious as the experimental class's students. Checking the test papers, the teacher discovers that the students in control class still seldom take notes as they have done in pre-test, which indicates their improvement has nothing to do with note-taking but because of traditional listening training. The data in Paired Sample t-test of experimental class for pre-test and post-test proves indicate the students in experimental class have improved a lot in post-test than in pre-test.

The data analysis from pre-questionnaire and post-questionnaire strengthens this conclusion.

From pre-questionnaire, it can be concluded that the general note-taking habits and experiences for both experimental class and control class students are quite similar before the experiment. The students have received much more instructions about how to take notes in Chinese class than in English class and in English listening comprehension they usually record no or very few notes, which also means they have the plasticity in English note-taking. They use both English and Chinese in note-taking in listening class but often give priority to English in listening comprehension test. Therefore, students in experimental class should be given intense note-taking training in order to find out whether note-taking strategy has a positive effect on college students' short passage listening comprehension.

From the post-questionnaire, it can be concluded that most of the students who have received the note-taking strategy training agree the strategy is very helpful for their short passage listening comprehension and their application to the strategy have also been improved, which is shown from statements 1, 3, 4, 5, 6, 8, 12, 13, 14 . This result is consistent with the result of note-taking from pre and post-tests. From statements 2 and 7, it can be seen that the effect of note-taking strategy on the comprehension of the whole passage is not very obvious, which indicates they only noted down the specific details rather than paying attention to the general ideas about the passage. From statements 11 and 15, we know 37\% students feel they don't have enough time to take notes while listening. They think the speech speed is too fast. Probably we could find the explanations for it after analysis of the content of the notes.

From the research of the content of the notes, it can be seen the index of content words is not significantly correlated with the students' listening comprehension performance and the index of the number of questions answerable from the notes is significantly correlated with the students' total scores in the test. Therefore, for the students who feel speech speed is too fast, they maybe need practice in detecting and recording the information-carrying words while ignoring structure words and other syntactic elements which do not add the information but only to increase the total number of the notes. It can be found from the questionnaire some students are in favor of writing down the full spelled content words rather than notations, which is not right. Although the notations are not significantly correlated with the listening performance, it is a very useful tactic to speed up writing down notes.

\section{Conclusion}

\subsection{Findings}

The major findings of the study can be summed up as follows:

Firstly, the results of data analysis indicate note-taking has a positive effect on students' listening performance and on listening comprehension test. This can also be explained in the aspect of memory mechanism and listening process. Di Vesta and Gray (1972) propose that note-taking has two functions: encoding function and external storage function. The former suggests taking notes facilitates information processing, while the latter suggests the review of notes stored in written form facilitates performance. The study also proved note-taking strategy training is helpful to short passage listening comprehension. The results in experimental class demonstrates the significance and necessity of note-taking strategy training in English listening teaching class and the students show higher enthusiasm in learning than those in control class who are taught in routine approach. The teacher's systematical introduction and reinforcement of note-taking strategy improved the experimental students' performance in listening a lot. The results from questionnaires show that students of experimental class hold positive attitude towards the two-month training of note-taking strategy. Although there are some distraction effects as a result of note-taking, this distraction can be overcome by practicing, by listening and talk notes simultaneously with sufficient listening and note-taking practice.

Secondly, taking notes as much as possible is not an efficient way to get high quality of notes. The number of questions answerable from the notes is proved closely correlated with the achievement of listening 
comprehension. The other three indices of the total number of notes, the content words notes and the notations have no significant correlation with subjects' quality of answers.

It can be concluded from all the above analysis, that the effective note-takers are those who compact large amounts of complicated monologue into useful information units and who transform content words (e.g., names, dates, statistics) to understandable abbreviations, symbols and so on.

\subsection{Implications}

The results of the study have positive implication not only in English listening comprehension teaching and learning but also in the whole process of foreign language teaching and learning.

It is imperative that the teachers should abandon the unreasonable aspects in the traditional method and pay more attention to the process of listening and choose appropriate practices which are suitable for note-taking strategy and for students' present ability so that students get used to taking notes to increase their ability of listening rather than simply add comprehensive input on them.

Although note-taking instruction is very helpful not only in the listening comprehension test but also in the academic learning in courses and interpreting work, some students still haven't had any note-taking instruction in their listening class. Therefore, it is urgent that note-taking should be considered as an important part in listening classes.

\subsection{Limitations}

Although the study has received many useful findings, still it has some defectives that should be improved.

Firstly, the study has focused on the note-taking strategy without regarding to other strategies.

Secondly, some variables such as different personalities, interests, learning styles and learning backgrounds of the subjects might affect the results of the study but without control of them.

Thirdly, because of the limitation of time and restriction of conditions, the scale of this empirical study is comparatively small to some degree.

\subsection{Suggestions}

We recommend that the following research be conducted to further pursue the findings of the study.

Firstly, all the subjects are from Inner Mongolia University for Nationalities. They might not be globally representative for all the Chinese EFL learners. Therefore, it's better to choose a great number of subjects at various levels in different universities by random sampling.

Secondly, in the further studies, incorporation of the well-defined variable of proficiency level into the design would introduce more accurate results.

Lastly, the relationship between the high quality-notes and the test performance should be explored more deeply. Indices in the present study have not been defined in a very systematic way. Thus, a more detailed classification of the indices measuring the content of notes is desirable. And the contributions of the indices of content word notes, notations and the total number of notes to achievement on listening comprehension are not measured directly in the study. Therefore, continued investigation of the content of students' notes may uncover additional indices of note-taking quality that more accurately reflect the performance of the note takers.

\section{Supporting Agencies}

This is the achievement of scientist research projects "Practical Research on English Listening Teaching Model of MOOC + SPOC + Flipped Classroom (YB20200034)", "Study on the Ways of Cultivating English Key Competencies of College Minority students (NGJGH2019080)" "Study on foreign language learning motivation and Teaching optimization of Mongolian teaching students in ethnic areas(2020JDMY09)" "The fourth (JGH2017088), fifth (JGH2018070), sixth (JGH2019054) and seventh (JGH2019012) blended teaching reform of Inner Mongolia University for Nationalities", "Analysis of English Majors' Pragmatic Failure and Countermeasures from the Perspective of Intercultural Communication (NMDYB19007)".

\section{References}

Alan, C. E. (2001). An investigation of note-taking as a predictor of course performance and course evaluation. Knoxville: University of Tennessee. https://doi.org/10.5703/1288284314995

Atkinson, R. C., \& Shiffrin, R. M. (1968). Human memory: A proposed system and its control processes. The Psychology of Learning and Motivation, 2, 89-195. https://doi.org/10.1016/S0079-7421(08)60422-3 
Baddeley, A. D. (1986). Working Memory. Oxford: Oxford University Press. https://doi.org/10.1017/s0033291700025228

Baddeley, A. D. (2007). Working Memory, Thought and Action. Oxford: Oxford University Press. https://doi.org/10.1093/acprof:oso/9780198528012.001.0001

Baddeley, A. D., \& Hitch, G. J. L. (1974). Working memory. The Psychology of Learning and Motivation: Advances in Research and Theory, 8, 47-89. https://doi.org/10.1016/s0079-7421(08)60452-1

Buck, G. (2001). Assessing Listening. Cambridge: Cambridge University Press. https://doi.org/10.1017/CBO9780511732959

Carrell, P. L., Dunkel, P. A., \& Mollaun, P. (2002). The Effect of Note-taking, Lecture Length, and Topic on the Listening Component of TCEFL2000. Princeton, NJ: Educational Testing Service. https://doi.org/10.21236/ADA120948

Carrier, K. A. (2003). Improving high school English language learner's second language listening through strategy instruction. Bilingual Research Journal, 27(3), 383-408. https://doi.org/10.1080/15235882.2003.10162600

Carroll, D. W. (1999). Psychology of Language. Pacific Grove: Brooks/Cole Publishing Company, Inc. https://doi.org/10.1016/0191-8036(90)90048-V

Chaudron, C., Cook, J., \& Loschky, L. (1988). Quality of Lecture Notes and Second Language Listening Comprehension. Honolulu: University of Hawaii at Manoa, Center for Second Language Classroom Research. https://doi.org/10.1017/CBO9781139524612.008

Chen, A. H. (2009). Listening strategy instruction: exploring Taiwanese college students' strategy development. Asian EFL Journal, 11(2), 54-85. https://doi.org/10.21559/aellk.2017.43.3.009

Di Vesta, F. J., \& Gray, G. S. (1972). Listening and note taking. Journal of Educational Psychology, 63, 8-14. https://doi.org/10.1037/h0032243

Dunkel, P. (1985). Listening and Note-taking: What is the Effect of Pre-training in Note-taking? TESOL Newsletter, 30-31. https://doi.org/10.2307/330073

Dunkel, P. (1988). The Content of L1 and L2 Students' Lecture Notes and Its Relation to Test Performance. TESOL Quarterly, 22(2), 259-281. https://doi.org/10.2307/3586936

Groeger, J. A. (1997). Memory and Remembering. Harlow Essex: Addison Wesley Longman Ltd. https://doi.org/10.2307/j.ctvwvr3jv.10

Hartley, J. (1983). Note taking research: Resetting the scoreboard. Bulletin of the British Psychological Society, 36, 13-14. https://doi.org/10.1016/S0007-1528(83)80057-1

Kiewra, K. A. (1985). Students' note taking behaviors and the efficacy of providing the instructor's notes for review. Contemporary Educational Psychology, 10, 378-386. https://doi.org/10.1016/0361-476x(85)90034-7

Klatzky, R. L. (1984). Memory and Awareness. WH: Freeman and Company. https://doi.org/10.1016/0091-2182(84)90157-5

Li, H. (2007). Note-taking strategies and college English listening teaching. Gansu Science and Technology, 23(4), 78-84.

Liu, Y. C. (2001). A Cognitive Study on the Functions of Note- taking and the Content of Notes Taken in a Context of Chinese EFL Learners (p. 56). Unpublished MA dissertation, Guangdong University of Foreign Studies.

Liu, Y. C. (2006). Cognitive psychology of note-taking: encoding and external storage for Chinese students listening to English lectures. Modern Foreign Languages, 26(2), 194-199.

Miller, G. (1968). The Psychology of Communication. Harmondsworth Middlesex: Penguin. https://doi.org/10.2307/2273017

Milliken, B., Joorden, S., Merikle, P. M. et al. (1998). Selective Attention: A reevaluation of The Implications of Negative Printing. Psychological Review, 2, 203-229. https://doi.org/10.1037/0033-295X.105.2.203

O’Malley, J. M., \& Chamot, A. U. (1990). Learning strategies in second language acquisition. Cambridge, England: Cambridge University Press. https://doi.org/10.1017/s0272263100010949 
Oxford, R. L. (1986). Development and psychometric testing of the Strategy Inventory for Language Learning (SILL) (pp. 86-92). ARI Technical Report 728. Alexandria, VA: Army Research Institute. Appendices as ARI Research Note. https://doi.org/10.1037/e412572004-001

Piolat, A., Olive, T., \& Kellogg, R. T. (2005). Cognitive Effort During Note-taking. Applied Cognitive Psychology, 19, 291-312. https://doi.org/10.1002/acp.1086

Rost, M. (2002). Teaching and Researching listening. London UK: Longman. https://doi.org/10.4324/9781315833705

Sternberg, R. J. (1999). Cognitive Psychology. Texas: Harcourt Brace College Publishers. https://doi.org/10.1177/003368829302400206

Tai, Z. H. (2015). A study on the note-taking strategies of TEM exam lectures. Foreign Language Testing and Teaching, 20(4), 7-16.

Tulving, E., \& Thomson, D. M. (1973). Encoding Specificity and Retrieval Processes in Episodic Memory. Psychological Review, 80, 353-357. https://doi.org/10.1037/h0020071

Yang, P. (2005). English listening note-taking from the perspective of cognitive psychology: A case study of TEM-8 note-taking. Journal of Inner Mongolia Normal University, 22(5), 130-133.

Zhou, S. B. (2007). Effects of note-taking on listening comprehension in English passages. Journal of Wenzhou Vocational and Technical College, 7(1).

\section{Appendix A}

\section{Pre-questionnaire}

Dear students,

Thank you for taking the time to read and complete this questionnaire. There is no right or wrong answer for each question. Please answer truthfully according to your own situation. Please write down your name and class before answering the questionnaire. Thank you very much for your cooperation!

Name: Class:

1) Have you ever had any classroom instruction in how to take notes in English?
A. Yes
B. No

2) (If "yes") how many total hours of classroom instruction have you had?
A. Less than one hour
B. One to three hours
C. Three to five hours
D. More than five hours

3) Have you ever had any classroom instruction on how to take notes n Chinese?
A. Yes
B. No

4) (If "yes") how many total hours of classroom instruction have you had?
A. Less than one hour
B. One to three hours
C. Three to five hours
D. More than five hours

5) How many notes do you usually take in English class?
A. None
B. Few
C. Some
D. A lot

6) How many notes do you usually take in Chinese classes?
A. None
B. Few
C. Some
D. A lot

7) In what language do you usually take notes in English class?
A. English
B. Chinese
C. Both

8) How many notes do you usually take on English listening comprehension test?
A. None
B. Few
C. Some
D. A lot

9) How many notes did you take on the test today?
A. None
B. Few
C. Some
D. A lot 
10) In what language did you take notes on the test today?
A. English
B. Chinese
C. Both

\section{Appendix B}

\section{Post-questionnaire}

Dear students,

Thank you for taking the time to read and complete the questionnaire. This questionnaire adopts the form of 3 subscales. Please select the intention consistent with your own situation from the three dimensions of "agree", "disagree" and "feel nothing" and draw " $\sqrt{ }$ " in the corresponding box. Please write down your name and class before answering the questionnaire. Thank you very much for your cooperation!

Name: Class:

\begin{tabular}{|c|c|c|c|c|}
\hline & & Agree & disagree & No strong feeling \\
\hline Statement 1 & Taking notes helps me answer questions better. & & & \\
\hline Statement 2 & Taking notes makes it more difficult for me to understand the passage. & & & \\
\hline Statement 3 & $\begin{array}{l}\text { Allowing me to take notes makes me feel more ease to answer the } \\
\text { questions. }\end{array}$ & & & \\
\hline Statement 4 & Taking notes makes it harder for me to answer questions. & & & \\
\hline Statement 5 & Taking notes helps me listen more carefully. & & & \\
\hline Statement 6 & Taking notes tends to distract me from the passage. & & & \\
\hline Statement 7 & Taking notes helps me understand the article better. & & & \\
\hline Statement 8 & Taking notes helps me remember the information more easily. & & & \\
\hline Statement 9 & I need more time to review my notes before I answer the question. & & & \\
\hline Statement 10 & I can use the notes I have taken when answering questions. & & & \\
\hline Statement 11 & I have enough time to take notes. & & & \\
\hline Statement 12 & $\begin{array}{l}\text { I find it difficult to listen to the test questions and at the same time to look } \\
\text { for the specific information in my notes. }\end{array}$ & & & \\
\hline Statement 13 & The article is too short and easy for me to take notes. & & & \\
\hline Statement 14 & I can find the answer from the notes I have taken. & & & \\
\hline Statement 15 & The speed is too fast to take notes. & & & \\
\hline
\end{tabular}

\section{Copyrights}

Copyright for this article is retained by the author, with first publication rights granted to the journal.

This is an open-access article distributed under the terms and conditions of the Creative Commons Attribution license (http://creativecommons.org/licenses/by/4.0/). 